\title{
INTEGRATING TECHNOLOGY AND DIGITAL CONNECTIVITY IN SERVICE RECOVERY STRATEGIES TO ACHIEVE RECOVERY SATISFACTION DURING THE COVID-19 PANDEMIC: A HYBRID APPROACH
}

\author{
Steven Kayambazinthu Msosa'
}

\begin{abstract}
Recently, the business landscape has changed because of the COVID-19 pandemic, which has led to changes in the behaviors of both customers and business owners. The COVID-19 pandemic and its associated restrictions on store closures have presented a new challenge to businesses that rely on physical interaction, brick and mortar to meet different customer needs. Mandatory shutdowns and social distancing measures have left voids that have been filled by digitalisation. The main problems customers face are service failures and breakdowns. As a result, customers are grappling with how they can have their problems addressed during the pandemic. There is therefore a need for a paradigm shift in terms of how businesses respond to unforeseen circumstances and pandemics because it is the only firm that use automation that will be more robust in competitive scenarios. This study is aimed at providing a hybrid approach to integrating digital technology into service recovery strategies, namely apology, explanation, speed, compensation and empowerment, during the COVID-19 pandemic in order to achieve customer recovery satisfaction. Therefore, a model for integrating technology and digital connectivity into service recovery strategies to achieve recovery satisfaction has been proposed. Thus, this model provides insight into how businesses can use digital technology to implement service recovery strategies during a pandemic. This is critical to help enterprises maintain consistency and minimize service variability due to changes caused by the COVID-19 pandemic. This study contributes to the literature on digital technology and service recovery by using current methods to address today's challenges.
\end{abstract}

Key words: service recovery strategies, technology, digital connectivity, customer service, COVID-19 pandemic, recovery satisfaction.

JEL Classification: M31, O31, L81, O33

\section{Introduction}

Since the outbreak of the COVID-19 pandemic, customer preferences have shifted. In light of today's business dynamics, service providers are struggling to find the best approach to meeting the diverse needs of their customers (Vader, Martin \& Lin, 2020). Moreover, managers are presently navigating how they might support customers in the wake of the COVID-19 pandemic, which has brought about numerous hurdles (Dixon, McKenna \& de la $\mathrm{O}$, 2020). The reality is that providing excellent customer service during a pandemic is a challenge because most customer service employees must work from home. Furthermore, many employees have to deal with personal issues whilst simultaneously meeting the needs of a diverse range of clients (Vardhan, 2021). Therefore, to facilitate customer interactions during the COVID-19 pandemic, businesses must foster Customer Relationship Management (Donthu \& Gustafsson, 2020). According to Kang et al. (2020), the pandemic has had a particularly negative impact on marketing processes because of the huge number of problems encountered in managing physical sales channels and customer relationships. In addition, customers are tired of being told that they are getting terrible service "due to Covid." In some cases, companies are accused of using the pandemic as an excuse for long phone waits or late deliveries. While businesses struggled with the consequences of the crisis, consumers were initially lenient about delays and other inconveniences. However, the broad justification is no longer acceptable (Peachey, 2021).

For most customers who are restricted to their homes, digital delivery has become an essential service.

Corresponding author:

${ }^{1}$ Mangosuthu University of Technology, South Africa.

E-mail: kayambazinthu@outlook.com

ORCID: https://orcid.org/0000-0001-9074-5644 
Customers who were once considered "digitally resistive" are now adopting technology at a rapid rate. It is expected that once the acute medical crisis is over, many customers who have switched to digital services will stay with them. Companies that make this transition to digital and create a superior experience have a chance to increase their customer base and retain relationships with them after the pandemic is over (Diebner, Silliman, Ungerman \& Vancauwenberghe, 2020). Consequently, companies must understand how the pandemic is affecting all consumer engagement touchpoints and ensure that they are not at the whim of such external occurrences in order to design a sustainable future in the 'new normal'. For business-toconsumer (B2C) organizations of all types, it's critical to recognize how far the modern customer experience has advanced and how different it can become. Understanding new behaviors will help companies navigate, respond and adapt their various touchpoints (Sharma \& Lacaze, 2020). Therefore, this study seeks to provide a hybrid approach to integrating technology and digital communications into service recovery strategies during the COVID-19 pandemic.

\section{Technology and digital connectivity during the COVID-19 pandemic}

The world has been forced into seclusion under COVID-19. Until everyone is vaccinated, social separation or distancing is the most efficient strategy to slow the spread of the virus. As a result, everything that depends on human-to-human contact (i.e., most elements of people's lives) must be changed to take into account the danger of the virus. Mandatory shutdowns and social distancing measures have left voids that have been filled by digitalisation (Cohron, Cummings, Laroia \& Yavar, 2020). Digitalization is the use of digital technology and digitized data to enable or improve processes. It improves, not transforms, an existing business process or processes. That is, it converts a human-driven event or set of events into a software-driven process (Gupta, 2020). Another school of thought argues that digitization refers to the reorganization of many aspects of social life around digital communication and media infrastructures. Individual, industrial, and regional prosperity has become dependent on the acquisition of digital skills (Bloomberg, 2018). The good news is that any business can be transformed by digital technology. Burket (2017) argues that they just need to figure out how to use or invent technology to solve problems or streamline procedures.

Integrating digitalization into all aspects of the economy increases productivity. According to Ashtonhart (2020), firms using automation will be more resilient in competitive scenarios. Thus, the need for digital technology (DT) has been demonstrated by
COVID-19, where traditional physical procedures are digitally modified to ensure continuity. DT provides connectivity, streamlines disparate processes, and reduces the likelihood of disruption during a pandemic (Fitzpatrick et al., 2020). One of the consequences of the COVID-19 disaster for businesses has been a major increase in the adoption of DT that assists firms to reduce face-to-face interactions whilst also protecting consumer and staff health and well-being. COVID-19 is an acute disruption right now, but it could recur or become a more chronic disruption in the future. This makes it difficult for executives leading their companies down the complex path of digital transformation to determine which digital steps are equivalent to an intense dose of azithromycin, and which pivots are needed to respond to constant and prolonged disruption (e.g., moving from on-premises to cloud computing) (Kane, Phillips, Copulsky \& Nanda, 2020).

The coronavirus is indefinitely changing the way people live and work. Some behaviors that emerged during the crisis, such as widespread use of the Internet, will persist long after the pandemic is over. Therefore, organizations must adapt to these behavioral changes and meet new customer needs in order to remain competitive. Advanced analytics will be used to extract information from customer data, and efforts will be made to integrate internal and external data to gain a more holistic view. Therefore, early detection of change signals will be critical to improving the customer experience and revising customer value propositions to meet changing market conditions, preferences and needs (Cohron, Cummings, Laroia \& Yavar, 2020). Figure 1 shows that as of January 2021, there were 4.66 billion active Internet users worldwide, representing 59.5 percent of the world's population. 92.6 percent ( 4.32 billion) used mobile devices to access the Internet (Statista, 2021). These statistics provide fertile ground for companies to integrate technology and digital connectivity into their business as the world's digital population is high.

\section{Theoretical background of service recovery}

Service recovery is a multi-dimensional concept that encompasses customers, employees and the process if a complaint is registered after a service failure (Kumar \& Kumar, 2016). Service recovery can be used as an effective weapon to gain a competitive advantage in a turbulent business environment (Singhal, Krishna \& Lazarus, 2013). Addison and Haig (2013) posit that service recovery, if properly executed, can turn angry customers into fanatics who will extol the service provider for top-notch service. Therefore, service providers are advised to consider the magnitude of service failure when designing recovery strategies. 


\section{Global digital population as of January 2021 (in billions)}

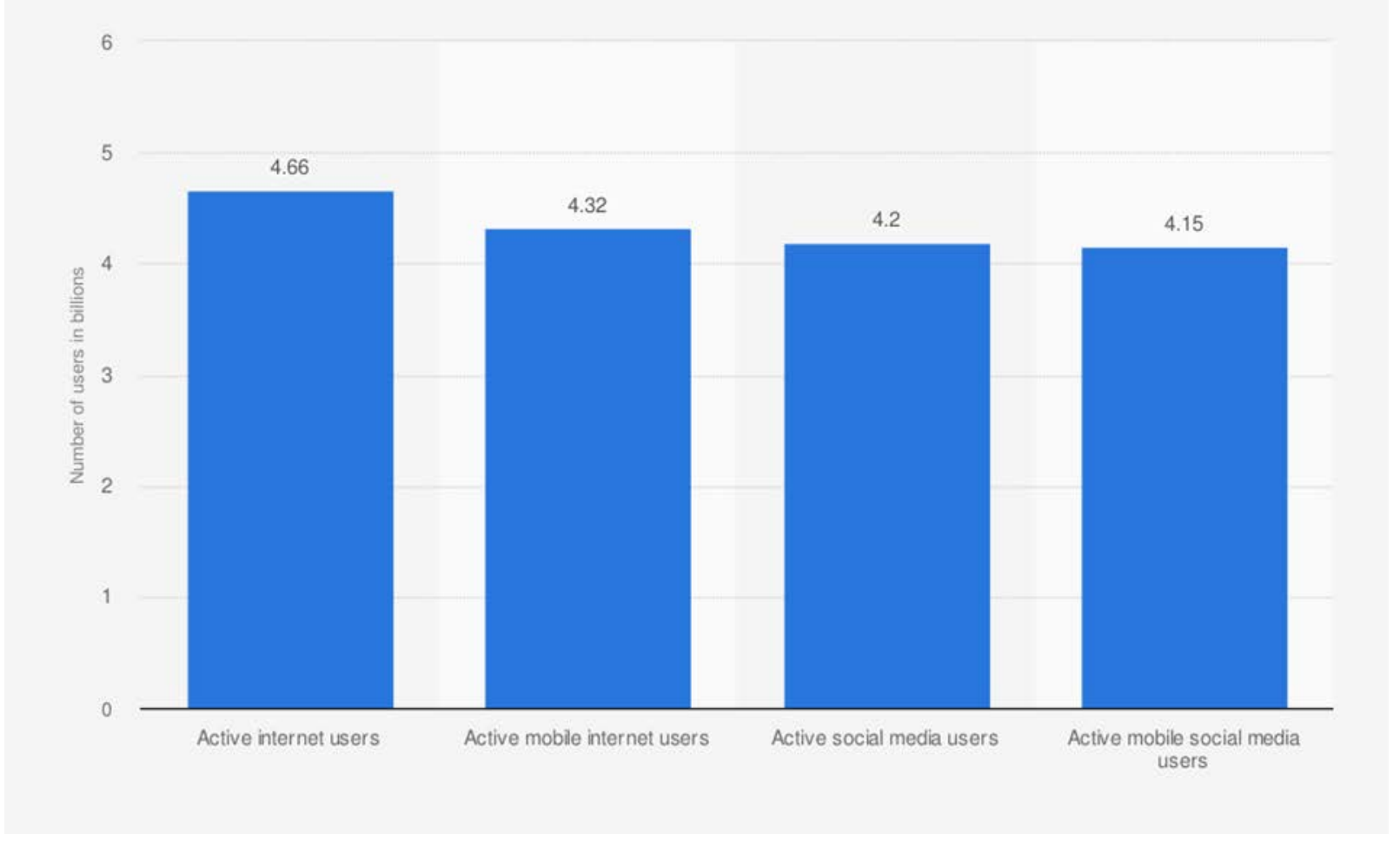

Figure 1. Global digital population

Source: Statista (2021)

Balaji and Sarkar (2013) warn that a service provider's inability to determine the severity of failure can lead to misallocation of resources and a firm's inability to satisfy and retain customers. The magnitude of the service failure determines the type of service recovery strategy that can be used to mitigate customer dissatisfaction. For example, if a customer suffered a financial loss, an apology would not be adequate because the customer would expect compensation from the service provider. In extreme cases, no amount of recovery performance or strategy will restore the customer to the previous position because of the damage caused by the initial failure. No matter the apology or size of compensation, any recovery tactic would not make the customer whole again and there is thus no way to recover (Mccollough, 2009). When service failure is severe, no amount of recovery or compensation is sufficient to please the customer. Chuang, Cheng, Chang and Yang (2012) made a finding that is consistent with the Prospect Theory, which contends that when the outcome and processrelated service failures are severe, it is not easy for the service provider to resolve the problem by either a tangible or psychological recovery approach. Simply put, customers believe that the losses associated with a denial of service are greater than the profits gained from service restoration efforts, so they consider any restoration efforts insufficient to mitigate the effects of a serious denial. The Prospect Theory and Mental Accounting principles suggest that the effectiveness of service recovery depends on the severity of the failure, such that service recovery strategies or tactics will be only effective when failure severity is low. With respect to gain and loss, as the severity of service failure becomes low, the perceived loss from failure and the perceived gain created by the effort to restore the service decrease, so that the customer will consider the loss to be less and the gain to be greater. The implication is that low service recovery efforts guarantee little benefit, but can be just as effective as high recovery efforts when peripheral services fail (Yi \& Lee, 2005).

\section{Service recovery strategies}

\subsection{Apology}

Brands with the best price, the most fashionable product, or the most memorable marketing campaign may not have an advantage over those who demonstrate emotional intelligence and communicate with care, honesty, and empathy, thereby inspiring trust. People want to be seen and understood in times of crisis, and they are especially sensitive to tone and intention (Acker, 2020). Therefore, service employees need to have a proper understanding of the problem and the 
experience of the customer. An apology on its own may not be enough. Customers want to be heard and feel that their stress and inconvenience is acknowledged and understood; that the service provider genuinely cares about them; and that efforts are being made to correct the problem (Michel \& Coughlan, 2009).

An apology is a service recovery method that does not directly fix the service failure, but rather implies that the service provider acknowledges the customer's problem and acknowledges that a mistake was made (Iglesias, Varela-Neira \& Vazquez-Casielles, 2015). While some researchers have emphasized the need for apologizing, Mostafa, Lages and Shabbir (2015) doubt the effectiveness of apologizing in increasing perceived justice. They believe that apologizing to customers can be interpreted as an admission of responsibility in some situations, thereby exacerbating the perception of interactional injustice. As a result, a discussion of the various sorts and dimensions of apology should be offered to facilitate comprehension. Managers should develop successful apology strategies, such as the channels used to deliver apology messages and acceptable methods for apologizing to disappointed consumers. By refusing to compensate consumers monetarily, they can save the company money (Jung \& Seock, 2017). Manica, Papagiannidis, and Bourlakis (2017) reflect on what is known as Social Media Apology. However, there are mixed views on the use of Social Media Apology in connection with a service provider's rejection. While the importance of using technology in the digital age to interact with customers is well known, such use should be approached with a degree of caution. The use of Social Media Apology, such as on Twitter and Facebook platforms, for service failure cases can reach customers who were not affected by the incident, which can have a negative impact on the organization's image.

\subsection{Speed}

The "locked down" nature of the response to the COVID-19 pandemic, which forces most people to be physically separated from their friends, extended family, workplaces and favourite places, is forcing businesses to adapt to a digital or remote way of doing business thereby dramatically altering people's daily experiences (Acker, 2020). However, as time passes, it becomes apparent that some of these modifications will remain long after COVID-19 ends, as customers have changed. Most consumers have higher customer service expectations now than before the epidemic, and they want quick and easy interaction with companies and stores (Ludwig, 2021). Van der Heijden et al. (2013) warned service providers to be wary of the time and effort spent interacting with customers to obtain information about a service failure event, as the time lost cannot be used to restore service failure, which can have a negative impact on the speed of service restoration. The period or time taken to respond to customer complaints should not be too long because the customer will not find the recovery effort or solution satisfactory. This is regardless of whether the service provider response was empathetic and caring, or not (Xu, Tronvoll \& Edvardsson, 2014).

Customers want to experience service recovery immediately after a service failure has occurred, and the burden is on them to make decisions about future consumption. Therefore, managers are encouraged to focus on immediate recovery solutions because recovery solutions that offer future solutions are less effective and desirable (Silber, Israel, Bustin \& Zvi, 2009). In contrast, Zhou, Tsang, Huang, and Zhou (2014) from another school of thought believe that service providers should consider delaying the provision of a solution in the event of a service failure because the elapsed time can calm the negative emotions caused by the service failure, thereby allowing customers to respond rationally to the service provider's recovery efforts. Conventional wisdom, however, suggests that restoration of services must be provided immediately to deal with service failures and customer complaints. The authors suggest that, under certain conditions, delayed response has a favorable effect. Some services, such as hairdressing, are inseparable, while some are separable, such as freight transportation. An immediate response is ideal for non-separated service failures because customers are very impatient with waiting and such cases magnify a customer's negative emotions.

\subsection{Compensation}

Compensation is an effective service recovery strategy. However, it is more effective if customers perceive it as a benevolent offer. Thus, service managers should advise employees to provide compensation in a way that shows sincere regret for the service failure (Lastner, Folse, Mnagus \& Fennell, 2016). Compensation is considered a very good service recovery strategy and helps defuse customer anger and dissatisfaction after a service failure. Service failure that is caused by a service provider leads to the lowest satisfaction, whereas service failure that is caused by the customer leads to the highest satisfaction with the same compensation ( $\mathrm{Fu}, \mathrm{Wu}$, Huang, Song \& Gong, 2015). Service managers must identify the different types of customers they deal with and choose the right type of compensation when a service failure occurs. Tsai, Yang and Cheng (2014) aver that service providers can go the extra mile by designing processes to allow employees to select compensation based on the characteristics of the consumer. 
Gelbrich and Roschk (2011) advise that to facilitate compensation, company procedures should not prescribe the type of compensation, but give employees the discretion to ask applicants about their expectations for an acceptable solution to the problem. Nikbin et al. (2015) believe that customers who are compensated after a failure of service will be confident that they will deal with the provider again without fear or risk of probable failure because they believe the provider will compensate them this time to restore the relationship. However, it should be noted that different compensation strategies do not produce the same degree of recovery satisfaction. Therefore, managers are advised to use different recovery tactics in different cases of failure of service $(\mathrm{Fu}, \mathrm{Wu}$, Huang, Song \& Gong, 2015). A high value of compensation leads to high satisfaction. In addition, in the case of financial loss due to a service failure, customers expect quality service restoration commensurate with the loss, and in some cases, compensation is appropriate if it restores the customer's condition before the failure occurred (Ellyawati, Pharmmesta, Purwanto \& Herk, 2013).

Consumers are subjected to different types of losses emanating from a similar type of failure. Singhal, Krishna and Lazarus (2013) coined a principle "like recovers like", meaning that compensation should be the same as that which was lost. In addition, the recipient of the complaint must be involved in the process of restoring services, because once he or she gets out of the picture, the customer loses faith and trust in the process, which can sometimes be difficult to restore. Yi and Lee (2005) argue that failure to provide services results in loss of economic and social resources, with economic resources recoverable through compensation and social resources recoverable through apologies.

\subsection{Empowerment}

Service failures can be discovered if the frontline can spot them when they occur, or if the customer brings the problem to the attention of the frontline employees. The frontline employee may have the ability to deal with the failure process while management is responsible for dealing with service failures related to financial situations. The level of authority given to employees determines the extent to which they can intervene when service failures are reported. This is so because managers draft company policy such that it is within their discretion to determine the limits and powers of employees (Schumacher \& Komppula, 2016). Institutional managers should keep an eye on analyzing the organisational structure and ensuring an optimal work environment through employee empowerment. This will make it easier for frontline employees to respond appropriately to certain service failure scenarios (Harun, Rokonuzzaman, Prybutok and Prybutok, 2018).

There is a link between how a company is organized and how effectively it adapts to chronic digital upheaval. More digitally savvy companies, in particular, are more likely to be organized around crossfunctional teams, and they are less likely to report that management processes and structures hinder their ability to work digitally. Companies that have reached digital maturity tend to give their employees more autonomy to make decisions, resulting in increased speed and flexibility (Kane, Phillips, Copulsky \& Nanda, 2020). Thus, employees represent the organization when complaints are registered, and they should be empowered to provide a small atonement that will appease disgruntled customers, rather than refer every issue to supervisors or managers. Therefore, organizations should empower employees to effectively handle customer complaints (Ekiz \& Khoo-Latimore, 2011).

Human Resources departments should avoid recruiting individuals with low efficacy and polychronicity to frontline positions since these employees have low self-confidence and prefer a self-learning and multitasking approach. These people would not be able to do the job successfully, and they would not help the company recover; instead, they would cause problems and possibly increase costs (Daskin \& Kasim, 2016). In addition, training and empowerment programs should be encouraged and developed so that, supported by recognition and rewards programs, employees are more likely to improve their service recovery performance (Abou \& Abou, 2013). In order to address errors that depend on individual staff, management should endeavour to promote an organisational culture that cultivates the right attitude by members of staff. Therefore, training should be arranged for employees so that they can quickly troubleshoot problems. This should be combined with service recovery processes and actions to compensate customers for problems encountered, thereby minimizing irritation and customer dissatisfaction (Zainol, 2012). According to Park and Ha (2016), service-oriented businesses should ensure that frontline personnel are well trained to conduct collaborative recovery processes in as constructive, considerate, and efficient a manner as possible. It is difficult for service workers who are not professionally trained to provide good service or maintain quality (Lee, Wu, Wu \& Liang, 2012). Nowadays, in order to improve the quality of service, the competencies of service personnel are critical, so there is a need to improve service knowledge. Two competencies that are critical to effective service delivery are employee skills and behavior (Skaalsvik, 2013). 


\subsection{Explanation}

The explanation does not produce any tangible results for the client. However, the tone and manner in which the explanation is given to the customer to explain the service situation can be related to interactional justice. The actual act of explaining is unrelated. In some cultures, explanation is used as a tool to resolve conflict and preserve harmony in society, so it is associated with procedural justice (Chern \& Hui, 2011). Service providers should determine or weigh the cost of service recovery strategies against the benefits, because sometimes the cost of recovery can increase enormously. Helping customers understand the reason for the failure of service by providing sufficient explanation is a powerful and low-cost strategy that managers can use to achieve effective and efficient service recovery efforts (Grewal, Roggeveen \& Tsiros, 2008).

Customers are always interested to know why there was an interruption in service. Therefore, a clear explanation can help calm a tense situation. For an explanation to be considered adequate, it must include the following characteristics. First of all, the content of the explanation must be correct and include relevant facts and information. Second, the delivery of explanations should reduce customer dissatisfaction. The most effective explanations are perceived as genuine, sincere and not manipulative (Wilson, Bitner, Zeithaml \& Gremler, 2012). While an explanation for service failure may seem like common sense, Bradley and Sparks (2012:48) caution service managers that not all employees provide an explanation. As a result, managers should encourage their employees to explain service errors because explanation is the most important and cost-effective tool for restoring customer happiness. The explanation makes customers feel good because it helps them understand why the service didn't work and reduces their conclusions about the reasons for the breakdown (Chern \& Hui, 2011).

\section{Criteria or considerations for using particular service recovery tactics}

The effectiveness of the service is determined via outcomes such as customer satisfaction, loyalty and retention (Miller, Craighead \& Karwan, 2000). Similarly, a great service recovery initiative will create consumers who are happy, content, optimistic, satisfied and relieved, rather than consumers who got nothing for the problems or failures they encountered (Keefe, Russel-Bennet \& Tombs, 2007). There are two service failure mitigation strategies, namely proactive and reactive strategies. Proactive strategies are used before a service failure occurs, while reactive strategies are used after a service failure. Proactive strategies include offering assurances of service quality and efforts to build rapport between the service provider and the client, while reactive strategies may include offering apologies, explanations, and compensation after a service failure (Worsfold, Worsfold \& Bradley, 2007).

Some service recovery strategies include apologizing (acknowledging the problem), helping (fixing the problem), and compensating (paying the cost of the problem). The challenge for service providers is to better understand which recovery strategy would be ideal in a particular situation (Levesque \& McDougall, 2000). For example, service failure caused by unfriendly service is more of a psychological factor, so efforts to restore service, such as providing money, may be inappropriate and fatal to the service provider, since in such a scenario the customer would expect an apology and an admission of responsibility for the service failure (Siagian \& Triyowati, 2015).

\section{Discussion}

\subsection{A hybrid approach to service recovery}

Service failures inevitably occur throughout the life cycle, and any effort to prevent them may be futile. However, service providers have a second chance to fix the situation with service recovery. Thus, the use of service recovery strategies like an apology, explanation, compensation, speed and empowerment can help the organization to restore customer confidence and pacify the angry customer. The challenge businesses face is how to adapt to a changing business environment where physical interaction or customer contact is becoming less and less desirable. The reality is that customer contact norms are changing in today's digital world. Therefore, organizations must identify and adapt to this new dynamic in order to continue to attract and retain customers. Businesses and their customers are rapidly adopting technology. Significant technology trends include social media, mobile computing, analytics and cloud computing. Even when considered separately, they have a significant impact on the customer experience. Moreover, taken together, these digital changes are extremely disruptive, creating both opportunities and risks for businesses (Deloite, 2013). Thus, it is becoming increasingly clear that technological advances and innovations will continue to be important in customer-firm interactions. These technological exchanges are predicted to become an important criterion for long-term corporate success (Meuter, Ostrom, Roundtree \& Bitner, 2000).

Clow and Baack (2018) believe that evolving technology has changed the way brands and companies are influenced. A customer facing a service failure is not limited to telling family and friends about it. Such a customer can use social media and instantly be heard by many customers in a short period of time. 
However, organizations are lucky because they can use the same technology to interact with customers and stimulate positive word-of-mouth. Therefore, businesses should consider using available digital platforms. For example, social media offers opportunities for two-way communication with consumers in their homes or other places of employment.

Integrating technology and digital connectivity into service recovery strategies will expand access to corporate facilities. As digital interactions with companies and stores expand, consumers expect to be served 24 hours a day, seven days a week. In circumstances where the consumers are trying to get help with difficulties on the site, they may be turned off and leave the sale entirely if they do not get prompt help. All types of organizations, including retailers and service providers, should have an employee on call to handle issues after hours. Customer support should be available around the clock because they work the same way. "Anything that brands deliver to customers today, especially digital services, should be available 24 hours a day, seven days a week" (Ludwig, 2021). People communicate with organizations through a variety of digital mediums, such as websites, review sites, social media, and so on, which requires a multi-channel customer experience. Businesses can synchronize communication with customers across channels using multichannel customer service technologies. This leads to more consistent contact between consumers and customer service representatives (Rodela, 2021). In this regard, companies must take an unbiased look at their operations, considering the possibility that a completely new approach is required. Channels, people, processes, technology and information all need to be considered as part of the operating model. During the operational model assessment, appropriate design concepts for today's digital world should be defined and utilized. This will allow for the identification of areas for improvement and the development of new skills (Deloite, 2013).

Technological advances now make it possible for customers to seek help and services from a corporation, even if they are in a remote location. Customers can

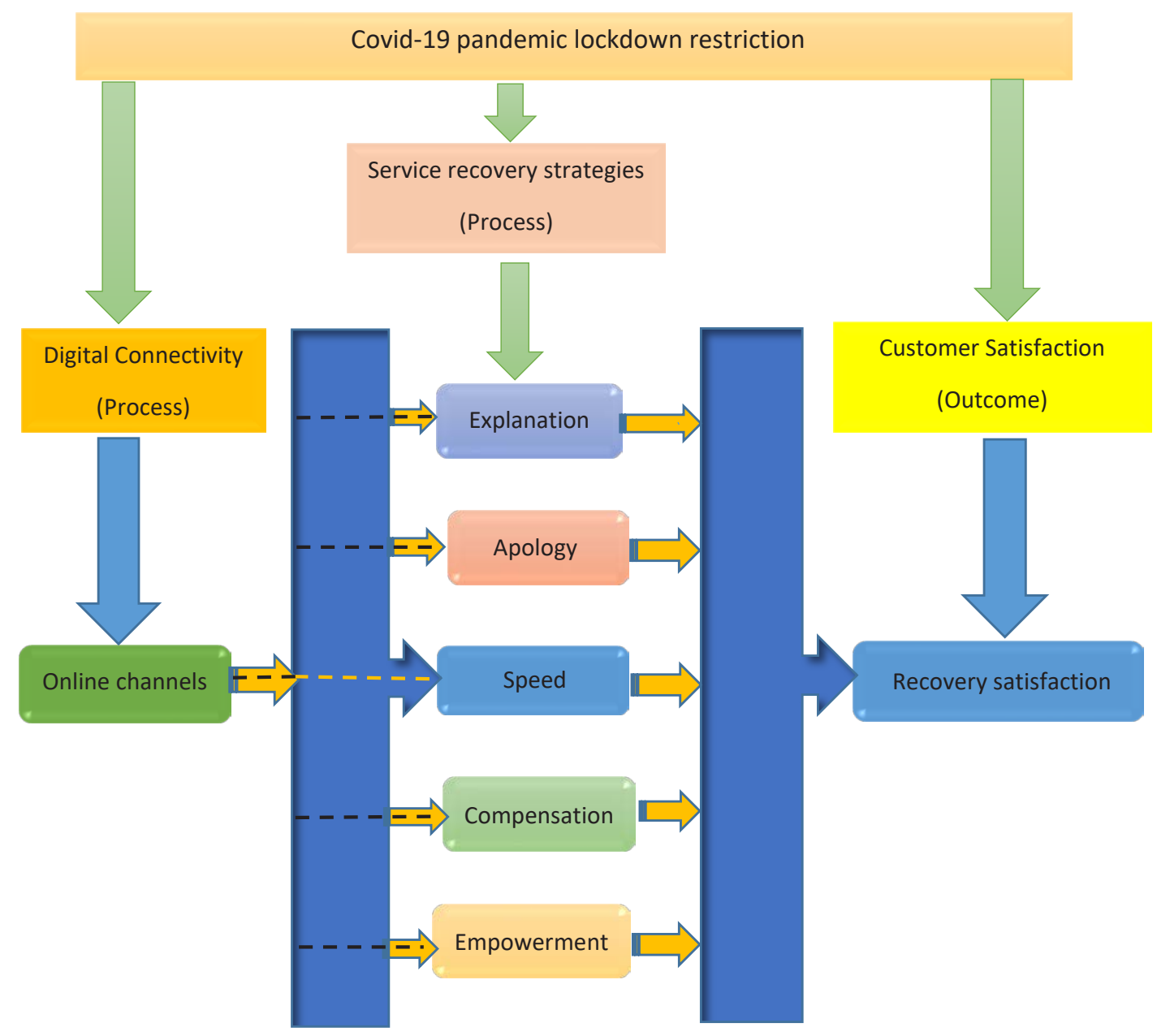

Figure 2. Technology and digital connectivity integrated service recovery framework

Source: author's construct 
communicate "face-to-face" with company experts through web video chats, remote online access and other technological techniques to help troubleshoot and solve problems. There are many other areas in which technology and customer service are inextricably linked, and it is up to companies to capitalize on both. Whatever a company decides to do and apply, it must remember that it must first understand the complex relationship between technology and customer service, and then use its power to become a strong force and partner of choice for even more customers (Newman, 2016). Therefore, this study proposes a framework that integrates technology and digital connectivity into service recovery strategies, namely speed, apology, compensation, explanation, and empowerment, as shown in Figure 2. Thus, integrating technology into the traditional way of doing business will help service providers offer seamless and timely service, which is critical, especially during a pandemic, due to restrictions imposed by several governments that make physical interaction less desirable.

\section{Conclusion}

The purpose of this paper was to propose a hybrid approach to integrating technology and digital capabilities into service recovery strategies, namely speed, apology, explanation, compensation, and empowerment, to achieve customer satisfaction with recovery. Newman (2016) believes that a company should focus on creating value for its customers at every stage and in every transaction and, despite the small number of human interactions, be able to form bonds and emotional connections with them. The enterprise should be able to improve the overall quality of service and interaction with its customers through the implementation of technological customer service. In today's fast-paced world, customers demand simplicity, convenience and flexibility to access a company's services from anywhere, anytime, because it gives them exactly what they want. This is the added value from the customer's perspective. Thus, providing excellent customer service today is the most important differentiator for any company or brand.

In an era of lockdowns and social distancing, businesses must develop ways to support customers and meet their needs. Managing time-starved customers requires a pragmatic approach, especially in this period of the COVID-19 pandemic. Regardless of sudden changes in business operations, the burden remains on the service provider to keep customers excited or risk customer attrition. The development of this concept was prompted by recent changes in the global economy. Therefore, businesses have an obligation to improve their processes or business models by integrating technology and digital connectivity so that they are available whenever needed and the level of customer service is more standardized and desirable. Ultimately, any service provider that is willing to adapt to change and make necessary adjustments in response to business uncertainty will be competitive and be able to retain satisfied and loyal customers.

\section{References:}

Abou, T. M., \& Abou, K. M. S. (20130. The influence of perceived service failure recovery strategies on customer satisfaction and loyalty in hotels. Research Journal of Management Sciences, 2(11), 16-24.

Acker, O. (2020). Redefining customer experience: Connecting in the time of COVID-19. Available at: https: / / www.strategy-business.com/blog/Redefining-customer-experience-Connecting-in-the-time-ofCOVID-19 (accessed August 25, 2021).

Addison, R., \& Haig, C. (2013). The hidden value of service recovery. Available at: http://www.bptrends.com/ $\mathrm{bpt} / \mathrm{wp}$-content/publicationfiles/02-05-2013-COL-PA-Value\%20of\%20Svc\%20Recovery--Addison $\% 20$ and $\% 20$ Haig.pdf (accessed 13 June 2017).

Ashton-hart, N. (2020). Leveraging Digital Connectivity for PostCOVID Competitiveness and Recovery. Available at: https://thecommonwealth.org/sites/default/files/inline/THT\%20162\%20FINAL.pdf (accessed 21 August 2021).

Balaji, M. S., \& Sarkar, A. (2013). Does successful recovery mitigate failure severity? a study of the behavioural outcomes in Indian context. International Journal of emerging markets, 8(1), 65-81.

Bloomberg, J. (2020). Digitization, Digitalization, And Digital Transformation: Confuse Them At Your Peril. Available at: https://www.forbes.com/sites/jasonbloomberg/2018/04/29/digitization-digitalization-and-digitaltransformation-confuse-them-at-your-peril/?sh=60f9f8ea2f2c (accessed 15 July 2021).

Bradley, G., \& Sparks, B. (2012). Explanations: if, when, and how they aid service recovery. Journal of Services Marketing, 26(1), 41-51.

Burket, D. (2017). Digitisation and Digitalisation: What Means What?. Available at: https://workingmouse.com.au/ innovation/digitisation-digitalisation-digital-transformation/ (accessed 30 August 2021).

Chern, B. H., \& Hui, T. L. (2011). Cultural differences in the Effect of an explanation on consumers' perceived justice and post-recovery satisfaction. Journal of Tourism, Hospitality and Culinary Arts, 3(2), 19-29.

Chuang, S. C., Cheng, Y. H., Chang, C. J., \& Yang, S. W. (2012). The effect of service failure types and service recovery on customer satisfaction: a mental accounting perspective. The Service Industries Journal, 32(2), $257-271$. 
Cohron, M., Cummings, S., Laroia, A., \& Yavar, E. (2020). COVID-19 is accelerating the rise of the digital economy. Available at: https://www.bdo.com/getattachment/07e769aa-5755-4151-9b52-4eeccfe61710/ attachment.aspx?ADV_DTS_COVID-19-is-Accelerating-the-Rise-of-the-Digital-Economy_Web.pdf (accessed 12 August 2021).

Daskin, M., \& Kasim, A., (2016). Exploring the impact of service recovery on customer affection, perceived value, and sabotaging behaviour: does gender make a difference? International Journal of Services and Operations Management, 23(4), 467-485.

Deloite (2013). The digital transformation of customer services: Our point of view. Available at: https://www2.deloitte.com/content/dam/Deloitte/nl/Documents/consumer-business/deloitte-nl-the-digitaltransformation-of-customer-services.pdf (accessed 20 August 2021).

Diebner, R., Silliman, E., Ungerman, K., \& Vancauwenberghe, M. (2020). Adapting customer experience in the time of coronavirus. Available at: https://www.mckinsey.com/business-functions/marketing-and-sales/ourinsights/adapting-customer-experience-in-the-time-of-coronavirus (accessed 25 August 2021).

Dixon, M., McKenna, T., \& de la O. G. (2020). Supporting customer Service through the Coronavirus crisis. Available at: https://hbr.org/2020/04/supporting-customer-service-through-the-coronavirus-crisis (accessed 10 August 2021).

Donthu, N., \& Gustafsson, A. (2020). Effects of COVID-19 on business and research. Journal of Business Research, 117, 284-289. DOI: https://doi.org/10.1016/j.jbusres.2020.06.008

Ekiz, E. H., \& Khoo-Lattimore, C. (2011). Factors influencing organizational responses to guest complaints: Cases of Hong Kong and Northern Cyprus. Estudios y Perspectivas en Turismo, 20(11), 673-705.

Ellyawati, J., Purwanto, B. M., \& Dharmmesta, B. S. (2012). The effect of perceived justice on customer satisfaction in the service recovery context: testing mediating variables. Journal of Service Science, 5(2), 87.

Fitzpatrick, M., Gill, I., Libarikian, A., Smaje, K., \& Zemmel, R. (2020) The digital-led recovery from COVID-19: Five questions for CEOs. McKinsey Digital. Available at: https://www.mckinsey.com/businessfunctions/mckinsey-digital/our-insights/the-digital-led-recovery-from-COVID-19-five-questions-for-ceos (accessed 21 August 2021).

Fu, H., Wu, D. C., Huang, S., Song, H., \& Gong, J. (2015). Monetary or non-monetary compensation for service failure. A study of customer preferences under various loci of casualty. International Journal of Hospitality Management, 46(1), 55-64.

Gelbrich, K., \& Roschk, H. (2011). A meta-analysis of organizational complaint handling and customer responses. Journal of Service Research, 14(1), 24-43.

Grewal, D., Roggeveen, A.L., \& Tsiros, M. (2008). The effect of compensation on repurchase intentions in service recovery. Journal of Retailing, 84(4), 424-434.

Gupta, M. S. (2020). What is Digitization, Digitalization, and Digital Transformation?. Available at: https://www.arcweb.com/blog/what-digitization-digitalization-digital-transformation (accessed 30 September 2021).

Harun, A., Rokonuzzaman, M., Prybutok, G. \& Prybutok, V.R., (2018). How to influence consumer mindset: A perspective from service recovery. Journal of Retailing and Consumer Services, 42, 65-77.

Iglesias, V., Varela-Neira, C., \& Vázquez-Casielles, R. (2015). Why didn't it work out? The effects of attributions on the efficacy of recovery strategies. Journal of Service Theory and Practice, 25(6), 700-724.

Jung, N. Y., \& Seock, Y. K. (2017). Effect of service recovery on customers' perceived justice, satisfaction, and word-of-mouth intentions on online shopping websites. Journal of Retailing and Consumer Services, 37, $23-30$.

Kane, G. C., Phillips, A. N., Copulsky, J., \& Nand, R. (2020). A case of acute disruption: Digital transformation through the lens of COVID-19. Available at: https://www2.deloitte.com/us/en/insights/topics/digitaltransformation/digital-transformation-COVID-19.html (accessed 10 April 2021).

Kang, J., Diao, Z., \& Zanini, M. T. (2020). Business-to-business marketing responses to COVID-19 crisis: A business process perspective. Marketing Intelligence and Planning. DOI: https://doi.org/10.1108/MIP-052020-0217 (accessed 21 April 2021).

Keeffe, D. A., Russell-Bennett, R., \& Tombs, A. (2007). The Intentional use of service recovery strategies to influence consumer emotion, cognition and behaviour. In: Hartel, C. E. J., Zerbe, W. J., \& Ashkanasy, N. M. (Eds.) Research on Emotions in Organizations: Functionality, Intentionality and Morality, Elsevier, Atlanta, Ga: 141-175.

Kumar, M., \& Kumar, N. (2016). Three dimensions of service recovery: examining relationship and impact. Supply Chain Management: An International Journal, 21(2), 273-286.

Lastner, M. M., Folse, J. A. G., Mangus, S. M., \& Fennell, P. (2016). The road to recovery: Overcoming service failures through positive emotions. Journal of Business Research, 69(10), 4278-4286.

Lee, L., Wu, W., Fu, C., \& Liang, H. (2012). The effects of service failure and service e recovery on consumers' post-recovery behaviours. International Journal of Social Sciences and Education, 2(1), 612-636.

Levesque, T. J., \& McDougall, G. H. (2000). Service problems and recovery strategies: an experiment. Canadian Journal of Administrative, 17(1), 20-37.

Ludwig, S. (2021). 5 Customer Service Trends That Are Here to Stay. Available at: https://www.uschamber.com/ co/grow/customers/post-pandemic-customer-service-trends (accessed 25 August 2021). 
Manika, D., Papagiannidis, S., \& Bourlakis, M. (2017). Understanding the effects of a social media service failure apology: A comparative study of customers vs. potential customers. International Journal of Information Management, 37(3), 214-228.

McCollough, M. A. (2009). The recovery paradox: The effect of recovery performance and service failure severity on post-recovery customer satisfaction. Academy of Marketing Studies Journal, 13(1), 89-104.

Meuter, M. L., Ostrom, A. L., Roundtree, R. I., \& Bitner, M. J. (2000). Self-service technologies: understanding customer satisfaction with technology-based service encounters. Journal of Marketing, 64(3), 50-64.

Michel, S., \& Coughlan, S. (2009). The service recovery paradox: Dispelling the myth. Perspectives for Managers, 174, 1-3.

Miller, J. L., Craighead, C. W., \& Karwan, K. R. (2000). Service recovery: a framework and empirical investigation. Journal of Operations Management, 18(4), 387-400.

Mostafa, R. B., Lages, C. R., Shabbir, H. A., \& Thwaites, D. (2015). Corporate image: A service recovery perspective. Journal of Service Research, 18(4), 468-483.

Newman, E. (2016). Relationship between Technology and Customer Service. Available at: https://corp.yonyx.com/ customer-service/relationship-between-technology-and-customer-service/ (accessed 21 August 2021).

Nikbin D., Marimuthu, M., Hyun, S. S., \& Ismail, I. (2015). Relationship of perceived justice to service recovery, service failure attribution, recovery satisfaction, and loyalty in the context of airline travellers. Asia Pacific Journal of Tourism Research, 20(3), 239-262.

Park, J., \& Ha, S. (2016). Co-creation of service recovery: Utilitarian and hedonic value and post-recovery responses. Journal of Retailing and Consumer Services, 28, 310-316.

Peachey, K. (2021). Customers fed up with Covid excuse for bad service. Available at: https://www.bbc.com/ news/business-57734808 (accessed 25 August 2021).

Rodela, J. (2021). Tried and Tested Ways Technology Can Improve Your Customer Service. Available at: https://www.fool.com/the-blueprint/customer-service-technology/ (accessed 24 September 2021).

Schumacher, S., \& Komppula, R. (2016). A case study on service recovery: Frontline employees' perspectives and the role of empowerment. European Journal of Tourism, Hospitality and Recreation, 7(2), 117-127.

Siagian, Y. M., \& Triyowati, H. (2015). Service recovery based on perceived justice: A study on locus attribution. International Journal of Business and Management, 10(7), 99.

Silber, I., Bustin, A., \& Zvi, O. B. (2009). Recovery strategies for service failures: the case of restaurants. Journal of hospitality marketing and management, 18, 730-740.

Singhal, S., Krishna, A., \& Lazarus, D. (2013). Service failure magnitude and paradox: a banking perspective. Journal of Relationship Marketing, 12(1): 191-203.

Skaalsvik, H., (2013). Understanding Service Failures: Suggesting a Competency Perspective. Journal of Tourism Research \& Hospitality, 2(2), 10: 2.

Statista (2021). Global digital population as of January 2021. Available at: https://www.statista.com/ statistics/617136/digital-population-worldwide/ (accessed 22 August 2021).

Tsai, C., Yang, Y., \& Cheng, Y. (2014). Does relationship matter? Customer response to service failure. Managing service quality, 24(2), 139-159.

Vader, R., Martin, P., \& Lin, W. (2020). Pleasing customers during a pandemic: Important lessons from China on how COVID-19 has changed customer behaviour. Available at: https://home.kpmg/xx/en/home/ insights/2020/03/pleasing-customers-during-a-pandemic.html (accessed 10 August 2021).

Van der Heijden, G. A. H., Schepers, J. L., Nijssen, J. E., \& Ordanini, A. (2013). Don't just fix it, make it better: using frontline service employees to improve recovery performance. Journal of the Academy of Marketing and Science, 41, 515-530.

Vardhan, H. (2021). Delivering Great Customer Service During a Pandemic: A Guide. Available at: https://hiverhq.com/blog/customer-service-coronavirus-pandemic (accessed 21 August 2021).

Wilson, A., Zeithaml, V. A., Bitner, M. J., \& Gremler, D. D. (2012). Services marketing: Integrating customer focus across the firm. Berkshire: McGraw Hill.

Worsfold, K., Worsfold, J., \& Bradley, G. (2007). Interactive effects of proactive and reactive service recovery strategies: The case of rapport and compensation. Journal of Applied Social Psychology, 37 (11), 2496-2517.

$\mathrm{Xu}$, Y., Tronvoll, B., \& Edvardsson, B. (2014). Recovering service failure through integration. The Services Industry Journal, 34(16), 1253-1271.

Yi, Y., \& Lee, J. (2005). An empirical study on the customer responses to service recovery in the context of service failure. Seoul Journal of Business, 11(1), 1-17.

Zainol, N. A. (2012). Identifying service failures among resort customers in Langkawi Island. International Conference on Trade, Tourism and Management (ICTM). Bangkok, Thailand.

Zhou, Y., Tsang, A. S., Huang, M., \& Zhou, N. (2014). Does delaying service-failure resolution ever make sense? Journal of Business Research, 67(2), 159-166. 